\title{
Association Analysis Between Polymorphism of Gonadotrophin Releasing Hormone Genes and Growth Traits of Quail (Coturnix Coturnix)
}

Original Article

-Author(s)

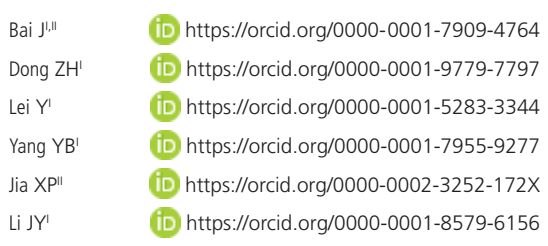

Henan University of Science and Technology, College of Animal Science and Technology, Luoyang 471003, China.

Henan University of Science and Technology, College of Agricultural,Luoyang 471003, China.

\section{Mail Address}

Corresponding author e-mail address Junyan Bai

Henan University of Science and Technology, 263 Kaiyuan Avenue, Luolong District,

Luoyang City, 471003, China.

Phone: 1868-4780095

Email: junyanb@163.com

\section{ABSTRACT}

This study investigated SNP mutation sites of Gonadotrophin releasing hormone $(\mathrm{G} n \mathrm{RH})$ gene in China yellow quail, Beijing white quail and Korean quail through PCR amplification and DNA sequencing technologies. Moreover, polymorphism of GnRH gene and its association with growth traits of quail were analyzed, aiming to get molecular markers associated to growth traits of quail, which could provide references for breeding of new quail species. According to research results, a total of 14 SNP mutation sites of GnRH were detected in China yellow quail, Beijing white quail and Korean quail, which were C71T, C108T, C168T, C178T, A184G, C206T, A209C, C215T, A252G, A279T, C281T, C293G, C339T and C458T. Except that only 2 genotypes were detected for A209C and C281T in China yellow quail and Beijing white quail, 3 genotypes were detected for all of the remaining 12 SNP mutation sites in three quail species. Of the 14 SNP sites, C71T, A209C, C215T, C281T, C293G, C339T and C458T were significantly associated with body weight $(p<0.05), C 71 T, C 108 T, C 168 T, C 178 T$, A184G, C206T, C215T, A252G, C293G, C339T and C458T were significantly associated with shank length $(p<0.05)$, C71T, C215T, C293G and C458T were significantly associated with breastbone length $(p<0.05), A 209 C$ and C281T were significantly associated with shank circumference $(p<0.05)$.

\section{INTRODUCTION}

Gonadotrophin releasing hormone $(\mathrm{GnRH})$ is a decapeptide firstly gained from hypothalamus of pig by Schally's research team. It mainly includes three types, namely, GnRH-1, GnRH-2 and GnRH-3. Among them, GnRH-1 mainly exists in the hypothalamus and it is vital to gonad development and sexual maturity of animals. Gong et al. (2018) reported that the expression and distribution of $\mathrm{GnRH}$ were in the preoptic region and in the arcuate nucleus of ewe hypothalamus. $\mathrm{He}$ et al. (2009) demonstrated that the expression level of GnRH mRNA was significantly higher in the hypothalamus of the egg laying group than in that of the non-egg laying group in Xueshan chicken. Zhang et al. (2019) discovered that GnRH mRNA was expressed in corpus leteum tissues of sow during different gestation periods, and the expression level was consistent with corpus leteum functions in the gestation period. Hameed et al. (2020) discussed influences of GnRH gene and short-term progesterone combined with electrocardiogram (ECG) on reproduction parameters of anestrous Beetal goat during the nonbreeding stage. Wang et al. (2020) found a remarkable association between the SNPs of GnRH and sperm quality traits of Chinese water buffalo. Xu et al. (2011) found a highly significant association between 
G840327C of the GnRH-I gene and age at first egg (AFE) $(p<0.01)$, but no significant association was detected between G840327C and egg number at 300 days of age ( $p>0.05)$ in a Chinese chicken population. In addition, Zhang et al. (2016), Han et al. (2016), Ding et al. (2018) and Liu et al. (2017) studied expression laws of GnRH gene at different development stages of Sichuan white goose, Xupu goose, small tailed han sheep and Microtus brandti. These studies all elaborated the close relationship between GnRH and reproduction traits of animals. It can be used as an important candidate gene in the process of animal production.

Quail is a suitable experimental animal in multiple subjects, such as poultry propagation, histology, nutriology, hemadenology, embryology, physiology and pharmacology (Bai et al., 2016a, 2016b, 2016c, 2020). Rasul et al. (2019) analyzed the effects of different anti stress agents on the growth and meat quality of Japanese quail. Li et al. (2019) indicated that the black plumage color might be caused by increased production of MC1R and the white plumage color might be caused by increased production of ASIP in Japanese quail. Therefore, this study analyzed polymorphism of $\mathrm{GnRH}$ gene through sequencing technique, and investigated growth traits of quails, aiming to gain molecular markers related to growth traits. Research conclusions can provide references for breeding and marker-assisted selection of new species of egg quail.

\section{MATERIALS AND METHODS}

\section{Genomic DNA extraction of quail}

50 female samples of China yellow quail, Beijing white quail and Korean quail were collected, respectively. All samples were cultured in single cages which had been sterilized strictly before the experiment. Spraying sterilization was performed regularly to all cages during the experiment. All cages were piled up completely into four layers. The culture room was provided with 24 hour light/day and the quails were allowed to drink water and eat diet freely throughout the experiment. Feeds were supplemented artificially twice a day (morning and evening). The culture temperature and humidity were determined according to culture management requirements. When the feeding experiment ended at the age of 17 weeks, $5 \mathrm{~mL}$ blood was collected from the heart of each quail and genomic DNA was extracted by poultry whole blood DNA extraction kit.

\section{Measurement of growth traits}

The growth traits such as body weight, chest depth, chest width, breastbone length, body length, shank length and shank circumference were measured from quails at 7-17 weeks. The specific measurement methods were as follows:

Body weight $(\mathrm{g})$ : the electronic scale weighs the weight of quail.

Chest depth $(\mathrm{cm})$ : use vernier caliper to measure the distance from the first thoracic vertebra to the front of keel.

Chest width $(\mathrm{cm})$ : use vernier caliper to measure the body surface distance between the two shoulder joints.

Breastbone length $(\mathrm{cm})$ : measure the distance from the front of sternum to the end of sternum with tape measure.

Body length $(\mathrm{cm})$ : measure the distance between shoulder joint and ischial node along the body surface with a leather tape.

Shank length $(\mathrm{cm})$ : use vernier caliper to measure the linear distance from the joint on the tibia (metatarsal) to the third and fourth toes.

Shank circumference $(\mathrm{cm})$ : use cotton thread to circle the tibia and mark on the cotton thread, and then measure the length marked on the cotton thread with a tape measure.

\section{PCR amplification of GnRH gene}

In this experiment, GnRH-1 primers were designed according to $\mathrm{Pu}$ (2016), which were F-TCTTGGTTGGTGTTCTCCT and R-ATTGCTCAGCCTGGGAT. The expected amplification fragment size was $906 \mathrm{bp}$. The total volume of PCR amplification reaction system was $15 \mu \mathrm{L}$, containing $3.5 \mu \mathrm{L}$ deionized water, $1 \mu \mathrm{L}$ upstream primer, $1 \mu \mathrm{L}$ downstream primer, $2 \mu \mathrm{L}$ DNA template and $7.5 \mu \mathrm{L}$ $2 \times$ Taq PCR Mix. The PCR amplification program was as follows: initial denaturation for $5 \mathrm{~min}$ at $94{ }^{\circ} \mathrm{C}$, following it was 30 cycles of degeneration for $30 \mathrm{~s}$ at $94{ }^{\circ} \mathrm{C}$, annealing for $30 \mathrm{~s}$ at $59{ }^{\circ} \mathrm{C}$ and extension for 30s at $72{ }^{\circ} \mathrm{C}$, finally an extension for $7 \mathrm{~min}$ at $72{ }^{\circ} \mathrm{C}$. The reaction system was stored under $4{ }^{\circ} \mathrm{C}$.

\section{Data analysis}

PCR products of GnRH gene were sent to Beijing Qingke biological Co., Ltd. for sequencing. Chromas software was used to determine the genotype of the sequencing results. 
Bai J, Dong ZH, Lei Y, Yang YB, Jia XP, Li JYI
Association Analysis Between Polymorphism of Gonadotrophin Releasing Hormone Genes and Growth Traits of Quail (Coturnix Coturnix)
The model used for association analysis between GnRH gene and growth traits was as follows:

Analytical model: $\quad y_{\mathrm{ijkl}}=\mu+B_{\mathrm{i}}+W_{\mathrm{j}}+M_{\mathrm{k}}+e_{\mathrm{ijk} \mathrm{l}}$

$Y_{i j k l}$ is the phenotype value of traits, $\mu$ is the total mean value, $B_{i}$ is the effect of the $i$ th variety ( $i=1$, $2,3), W_{j}$ is the effect of the $j$ th Week age $(7,8,9,1$ $0,11,12,13,14,15,16,17), M_{k}$ is the effect of the $k$ th genotype effect, $e_{i j k l}$ is the residual effect.

SPSS17.0 statistical software was used to analyze the association between different genotypes and growth traits, the final results were represented in the form of mean value + standard error.

\section{RESULTS}

\section{Detection SNP sites}

PCR amplification products of GnRH gene in China yellow quail, Beijing white quail and Korean quail are shown in Figure 1. Clearly, the amplification fragments of GnRH gene all gave a high-definition bright stripe near 906bp, which conformed to the target size of $906 \mathrm{bp}$. A total of 14 SNP mutation sites of GnRH gene were detected in three egg quail species, which were C71T, C108T, C168T, C178T, A184G, C206T, A209C, C215T, A252G, A279T, C281T, C293G, C339T and C458T (Figure 2). Pu YJ. (2016) studied polymorphism of $\mathrm{GnRH}-1$ in quail, and detected 6 mutation sites including C108T, C168T, C178T, A184G, C206T and C215T, only C108T was silent mutation without causing changes to the corresponding amino acid. In this study, 8 additional mutation sites were detected besides the six ones above, which were C71T, A209C, A252G, A279T, C281T, C293G, C339T and C458T, demonstrating that GnRH-1 gene had rich polymorphism in 3 egg quail species.

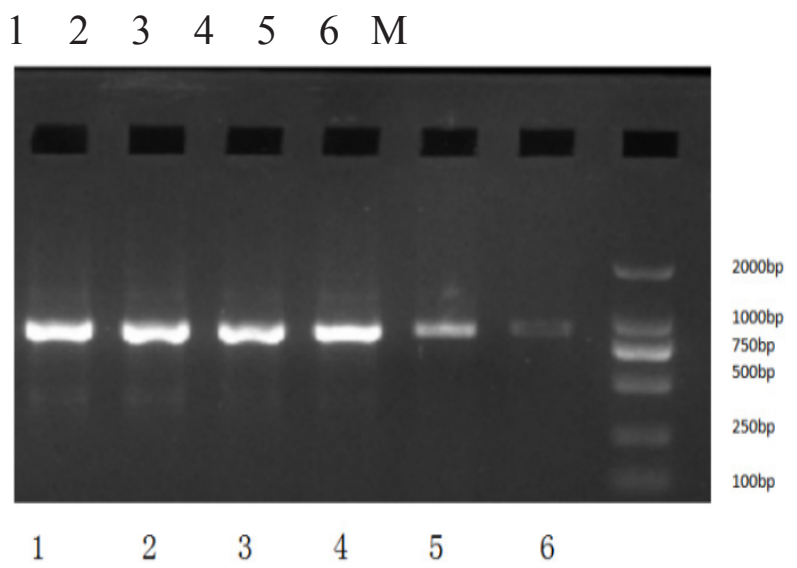

Figure 1 - Agarose electrophoresis results of GnRH-1 gene.

Note: $M$ is marker DL2000, 1,2 represent Chinese yellow quail, 3,4 represent Beijing white quail, 5,6 represent Korean quail.
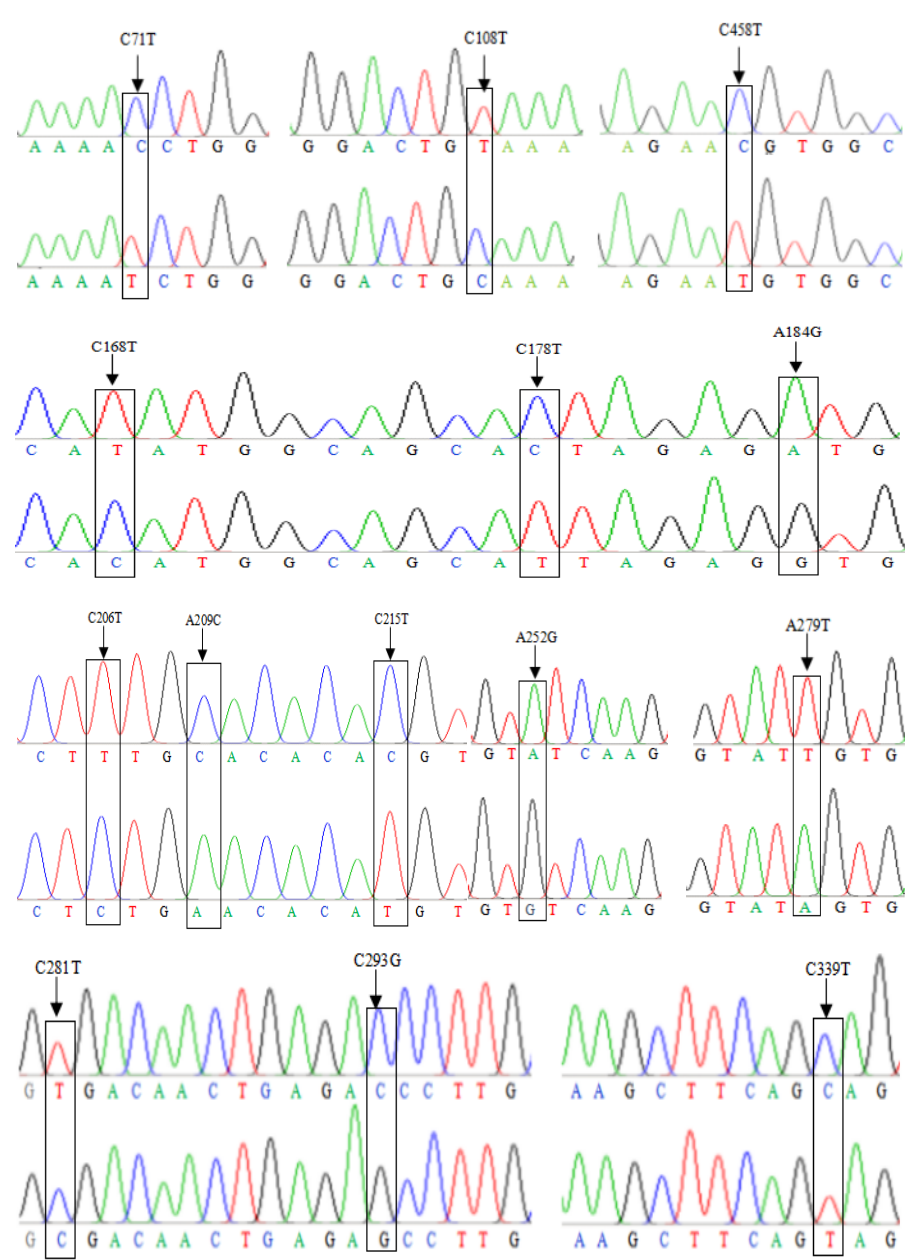

Figure 2 - SNP detection of GnRH-1 gene in quail.

\section{Genotype frequency}

Except that only 2 genotypes were detected for A209C and C281T in China yellow quail and Beijing white quail, the remaining 12 SNP mutation sites all detected 3 genotypes in three egg quail species. The frequencies of TT, CC, CC, TT, GG and CC genotypes were the highest for C71T, C108T, A209C, C281T, C293G and C339T respectively, which reached 0.479, $0.522,0.534$ (TT genotype frequency of C71T), 0.458, $0.500,0.438$ (CC genotype frequency of C108T), $0.980,0.955,0.624$ (CC genotype frequency of A209C), 0.980, 0.955, 0.708 (TT genotype frequency of (281T), 0.458, 0.523, 0.646 (GG genotype frequency of C293G), 0.833, 0.795, 0.688 (CC genotype frequency of (339T) in China yellow quail, Beijing white quail and Korean quail respectively.

\section{Association analysis between GnRH gene and growth traits}

It can be observed from Table 1 that for C71T mutation site, body weight and shank length of individuals with CT genotype were significantly 
Table 1 - Genotype frequency of GnRH gene.

\begin{tabular}{|c|c|c|c|c|c|c|c|c|c|}
\hline Locus & Genotype & $\begin{array}{c}\text { Chinese } \\
\text { yellow quail }\end{array}$ & $\begin{array}{c}\text { Beijing white } \\
\text { quail }\end{array}$ & Korean quail & Locus & Genotype & $\begin{array}{c}\text { Chinese } \\
\text { yellow quail }\end{array}$ & $\begin{array}{l}\text { Beijing white } \\
\text { quail }\end{array}$ & Korean quail \\
\hline \multirow[t]{3}{*}{ C71T } & CC & 0.104 & 0.159 & 0.042 & C215T & CC & 0.354 & 0.659 & 0.250 \\
\hline & $C T$ & 0.417 & 0.318 & 0.313 & & CT & 0.438 & 0.295 & 0.500 \\
\hline & $\mathrm{TT}$ & 0.479 & 0.522 & 0.534 & & $T T$ & 0.208 & 0.046 & 0.250 \\
\hline \multirow[t]{3}{*}{ C108T } & $C C$ & 0.458 & 0.500 & 0.438 & A252G & AA & 0.104 & 0.205 & 0.125 \\
\hline & $\mathrm{CT}$ & 0.417 & 0.319 & 0.417 & & $A G$ & 0.438 & 0.318 & 0.458 \\
\hline & $\mathrm{TT}$ & 0.125 & 0.181 & 0.146 & & GG & 0.458 & 0.477 & 0.417 \\
\hline \multirow[t]{3}{*}{ C168T } & $C C$ & 0.125 & 0.182 & 0.125 & A279T & $A A$ & 0.085 & 0.100 & 0.109 \\
\hline & $C T$ & 0.417 & 0.341 & 0.479 & & AT & 0.809 & 0.800 & 0.804 \\
\hline & $\mathrm{TT}$ & 0.458 & 0.477 & 0.396 & & $\pi$ & 0.106 & 0.100 & 0.087 \\
\hline \multirow[t]{3}{*}{ C178T } & $C C$ & 0.458 & 0.477 & 0.396 & C281T & CC & 0 & 0 & 0.063 \\
\hline & $C T$ & 0.417 & 0.341 & 0.438 & & $\mathrm{CT}$ & 0.020 & 0.045 & 0.229 \\
\hline & $\pi$ & 0.125 & 0.182 & 0.167 & & $\pi$ & 0.980 & 0.955 & 0.708 \\
\hline \multirow[t]{3}{*}{ A184G } & $A A$ & 0.458 & 0.477 & 0.375 & C293G & CC & 0.104 & 0.159 & 0.042 \\
\hline & $A G$ & 0.417 & 0.341 & 0.458 & & CG & 0.438 & 0.318 & 0.312 \\
\hline & GG & 0.125 & 0.182 & 0.167 & & GG & 0.458 & 0.523 & 0.646 \\
\hline \multirow[t]{3}{*}{ C206T } & CC & 0.125 & 0.182 & 0.187 & C339T & CC & 0.833 & 0.795 & 0.688 \\
\hline & $C T$ & 0.438 & 0.364 & 0.542 & & CT & 0.146 & 0.182 & 0.186 \\
\hline & $\mathrm{TT}$ & 0.437 & 0.454 & 0.291 & & $\pi$ & 0.021 & 0.021 & 0.125 \\
\hline \multirow[t]{3}{*}{ A209C } & $A A$ & 0 & 0 & 0.063 & C458T & $C C$ & 0.563 & 0.341 & 0.604 \\
\hline & $A C$ & 0.020 & 0.045 & 0.313 & & $\mathrm{CT}$ & 0.396 & 0.386 & 0.313 \\
\hline & CC & 0.980 & 0.955 & 0.624 & & TT & 0.041 & 0.273 & 0.083 \\
\hline
\end{tabular}

higher than those with CC genotype $(p<0.05)$, and the breastbone length of individuals with CC and TT genotypes were far higher than that with $C T$ genotype $(p<0.05)$. For C108T, C168T, C178T and C206T, shank length of individuals with CT genotype was far higher than that with CC and TT genotypes $(p<0.05)$. For $A 184 G$ and $A 252 G$, shank length of individuals with $A G$ genotype was far higher than that with AA and GG genotypes $(p<0.05)$. For A209C, body weight of individuals with $A A$ and $A C$ genotypes was dramatically higher than that with CC genotype $(p<0.05)$, shank circumference of individuals with $A A$ genotype was far higher than that with $A C$ and $C C$ genotypes $(p<0.05)$. C215T played an important role in body weight, shank length, breastbone length and shank circumference, due to the significantly higher body weight, shank length and shank circumference of CC and CT genotypes than TT genotype $(p<0.05)$, and significant higher breastbone length of $C C$ genotype than CT and TT genotypes $(p<0.05)$.

C281T had significant impact on body weight and shank circumference as body weights of CC and CT genotypes were dramatically higher than that of $\mathrm{TT}$ genotype $(p<0.05)$, and shank circumference of CC genotype was significantly higher than that of CT and TT genotypes $(p<0.05)$. For C293G, body weight of individuals with CG genotype was significantly higher than that with $C C$ and $G G$ genotypes $(p<0.05)$, breastbone length of individuals with $C C$ and $G G$ genotypes was greatly higher than that with CG genotype $(p<0.05)$. For C339T, body weight and shank length of individuals with TT genotype were far higher than that with CC and CT genotypes $(p<0.05)$. With respect to $C 458 \mathrm{~T}$, body weight of $\mathrm{CT}$ and $\mathrm{TT}$ genotypes was far higher than that of CC genotype $(p<0.05)$, and shank length of $\mathrm{CT}$ genotype was significantly higher than that of CC genotype $(p<0.05)$, breastbone length of TT genotype was far higher than that of CC and CT genotypes $(p<0.05)$. Generally, GnRH gene influenced growth traits of egg quail.

Du QZ (2011) demonstrated that for A883G of GnRH gene, the original sperm activity of individuals with $A B$ genotype was far higher than that with $B B$ genotype in Holstein cattle, based on which, he deduced that $A$ allele might be positively related with characteristics of original sperms. Wang et al. (2020) found a remarkable association between the SNPs of GnRH and sperm quality traits of Chinese water buffalo. Xu et al. (2011) found a highly significant association between G840327C of the GnRH-I gene and age at first egg (AFE) $(p<0.01)$ in a Chinese chicken population. Li et al.(2016) pointed out that for T68G of GnRH, lambing number of GG genotype was far higher than that of the rest two genotypes in Rongjiang little sweet sheep. Yan et al. (2011) pointed out that P4 amplification fragment of $\mathrm{GnRH}$ gene influenced lambing number of both Sinonsa milk goat and Boer goat significantly. Huang et al. (2011) demonstrated that three genotypes 
Table 2 - Correlation analysis between GnRH gene and growth traits of quail.

\begin{tabular}{|c|c|c|c|c|c|c|c|c|}
\hline Locus & Genotype & Body weight(g) & $\begin{array}{c}\text { Shank } \\
\text { length }(\mathrm{cm})\end{array}$ & $\begin{array}{c}\text { Chest } \\
\text { width }(\mathrm{cm})\end{array}$ & $\begin{array}{c}\text { Chest } \\
\text { depth }(\mathrm{cm})\end{array}$ & $\begin{array}{l}\text { Breastbone } \\
\text { length }(\mathrm{cm})\end{array}$ & Body length $(\mathrm{cm})$ & $\begin{array}{c}\text { Shank circumference } \\
(\mathrm{cm})\end{array}$ \\
\hline \multirow[t]{3}{*}{ C71T } & CC & $162.034 \pm 2.486^{b}$ & $3.569 \pm 0.013^{b}$ & $3.182 \pm 0.021^{a}$ & $3.294 \pm 0.026^{a}$ & $4.408 \pm 0.026^{a}$ & $9.224 \pm 0.061^{\mathrm{a}}$ & $1.677 \pm 0.014^{\mathrm{a}}$ \\
\hline & $\mathrm{CT}$ & $165.006 \pm 0.975^{a}$ & $3.621 \pm 0.008^{a}$ & $3.157 \pm 0.011^{\mathrm{a}}$ & $3.309 \pm 0.013^{a}$ & $4.329 \pm 0.011^{\mathrm{b}}$ & $9.180 \pm 0.031^{a}$ & $1.679 \pm 0.006^{a}$ \\
\hline & $\mathrm{TT}$ & $164.014 \pm 0.815^{\mathrm{ab}}$ & $3.606 \pm 0.007^{a}$ & $3.188 \pm 0.009^{a}$ & $3.338 \pm 0.011^{a}$ & $4.380 \pm 0.010^{a}$ & $9.243 \pm 0.022^{\mathrm{a}}$ & $1.684 \pm 0.005^{a}$ \\
\hline \multirow[t]{3}{*}{ C108T } & $\mathrm{CC}$ & $163.647 \pm 0.865^{a}$ & $3.596 \pm 0.007^{b}$ & $3.187 \pm 0.010^{a}$ & $3.332 \pm 0.012^{a}$ & $4.385 \pm 0.011^{a}$ & $9.240 \pm 0.025^{a}$ & $1.683 \pm 0.005^{a}$ \\
\hline & $\mathrm{CT}$ & $165.264 \pm 0.990^{a}$ & $3.632 \pm 0.008^{a}$ & $3.162 \pm 0.010^{a}$ & $3.321 \pm 0.013^{a}$ & $4.342 \pm 0.010^{a}$ & $9.190 \pm 0.029^{a}$ & $1.677 \pm 0.006^{a}$ \\
\hline & $\pi$ & $162.921 \pm 1.773^{a}$ & $3.579 \pm 0.011^{b}$ & $3.181 \pm 0.017^{a}$ & $3.304 \pm 0.021^{a}$ & $4.360 \pm 0.023^{a}$ & $9.224 \pm 0.047^{a}$ & $1.687 \pm 0.011^{a}$ \\
\hline \multirow[t]{3}{*}{ C168T } & $\mathrm{CC}$ & $162.971 \pm 1.856^{a}$ & $3.575 \pm 0.011^{\mathrm{b}}$ & $3.179 \pm 0.017^{a}$ & $3.297 \pm 0.021^{\mathrm{a}}$ & $4.357 \pm 0.024^{a}$ & $9.217 \pm 0.049^{a}$ & $1.684 \pm 0.011^{\mathrm{a}}$ \\
\hline & CT & $165.173 \pm 0.928^{a}$ & $3.630 \pm 0.008^{a}$ & $3.166 \pm 0.010^{a}$ & $3.325 \pm 0.012^{a}$ & $4.348 \pm 0.010^{a}$ & $9.201 \pm 0.027^{a}$ & $1.680 \pm 0.005^{a}$ \\
\hline & $\mathrm{TT}$ & $163.603 \pm 0.904^{a}$ & $3.596 \pm 0.008^{b}$ & $3.185 \pm 0.010^{a}$ & $3.330 \pm 0.012^{a}$ & $4.383 \pm 0.011^{\mathrm{a}}$ & $9.235 \pm 0.025^{\mathrm{a}}$ & $1.682 \pm 0.005^{a}$ \\
\hline \multirow[t]{3}{*}{ C178T } & $C C$ & $163.603 \pm 0.904^{a}$ & $3.596 \pm 0.008^{b}$ & $3.185 \pm 0.010^{a}$ & $3.330 \pm 0.012^{\mathrm{a}}$ & $4.383 \pm 0.011^{\mathrm{a}}$ & $9.235 \pm 0.025^{\mathrm{a}}$ & $1.682 \pm 0.005^{a}$ \\
\hline & $C T$ & $164.832 \pm 0.944^{a}$ & $3.628 \pm 0.008^{a}$ & $3.162 \pm 0.010^{\mathrm{a}}$ & $3.321 \pm 0.012^{\mathrm{a}}$ & $4.345 \pm 0.010^{a}$ & $9.202 \pm 0.028^{a}$ & $1.679 \pm 0.005^{a}$ \\
\hline & $\mathrm{TT}$ & $164.071 \pm 1.753^{a}$ & $3.586 \pm 0.011^{b}$ & $3.189 \pm 0.017^{a}$ & $3.311 \pm 0.021^{a}$ & $4.366 \pm 0.022^{\mathrm{a}}$ & $9.214 \pm 0.046^{a}$ & $1.686 \pm 0.010^{a}$ \\
\hline \multirow[t]{3}{*}{ A184G } & $\mathrm{AA}$ & $163.335 \pm 0.912^{a}$ & $3.596 \pm 0.008^{b}$ & $3.182 \pm 0.010^{a}$ & $3.327 \pm 0.012^{a}$ & $4.381 \pm 0.011^{\mathrm{a}}$ & $9.234 \pm 0.026^{a}$ & $1.681 \pm 0.005^{a}$ \\
\hline & $A G$ & $165.094 \pm 0.934^{a}$ & $3.628 \pm 0.008^{a}$ & $3.166 \pm 0.010^{a}$ & $3.324 \pm 0.012^{\mathrm{a}}$ & $4.347 \pm 0.010^{a}$ & $9.203 \pm 0.028^{a}$ & $1.679 \pm 0.005^{a}$ \\
\hline & GG & $164.071 \pm 1.753^{a}$ & $3.586 \pm 0.011^{b}$ & $3.189 \pm 0.017^{a}$ & $3.311 \pm 0.021^{\mathrm{a}}$ & $4.366 \pm 0.022^{a}$ & $9.214 \pm 0.046^{a}$ & $1.686 \pm 0.010^{a}$ \\
\hline \multirow[t]{3}{*}{ C206T } & $\mathrm{CC}$ & $164.071 \pm 1.753^{a}$ & $3.586 \pm 0.011^{b}$ & $3.189 \pm 0.017^{\mathrm{a}}$ & $3.311 \pm 0.021^{a}$ & $4.366 \pm 0.022^{\mathrm{a}}$ & $9.214 \pm 0.046^{a}$ & $1.686 \pm 0.010^{a}$ \\
\hline & $\mathrm{CT}$ & $165.610 \pm 0.883^{a}$ & $3.630 \pm 0.007^{a}$ & $3.174 \pm 0.010^{\mathrm{a}}$ & $3.330 \pm 0.012^{\mathrm{a}}$ & $4.349 \pm 0.009^{a}$ & $9.214 \pm 0.026^{a}$ & $1.681 \pm 0.005^{a}$ \\
\hline & $\mathrm{TT}$ & $162.546 \pm 0.964^{a}$ & $3.590 \pm 0.008^{b}$ & $3.174 \pm 0.011^{\mathrm{a}}$ & $3.320 \pm 0.013^{a}$ & $4.383 \pm 0.012^{\mathrm{a}}$ & $9.226 \pm 0.027^{a}$ & $1.680 \pm 0.006^{a}$ \\
\hline \multirow[t]{3}{*}{ A209C } & $\mathrm{AA}$ & $169.157 \pm 2.391^{a}$ & $3.674 \pm 0.027^{\mathrm{a}}$ & $3.255 \pm 0.035$ & $3.391 \pm 0.057^{a}$ & $4.271 \pm 0.049^{a}$ & $9.305 \pm 0.087^{a}$ & $1.743 \pm 0.016^{a}$ \\
\hline & $A C$ & $171.498 \pm 1.852^{a}$ & $3.663 \pm 0.015^{a}$ & $3.233 \pm 0.016^{a}$ & $3.382 \pm 0.021^{a}$ & $4.371 \pm 0.022^{a}$ & $9.274 \pm 0.046^{a}$ & $1.686 \pm 0.011^{b}$ \\
\hline & $\mathrm{CC}$ & $162.970 \pm 0.656^{b}$ & $3.598 \pm 0.005^{a}$ & $3.166 \pm 0.007^{a}$ & $3.313 \pm 0.009^{a}$ & $4.366 \pm 0.008^{a}$ & $9.208 \pm 0.019^{a}$ & $1.679 \pm 0.004^{b}$ \\
\hline \multirow[t]{3}{*}{ C215T } & $\mathrm{CC}$ & $164.971 \pm 0.920^{a}$ & $3.609 \pm 0.007^{a}$ & $3.181 \pm 0.010^{\mathrm{a}}$ & $3.322 \pm 0.012^{a}$ & $4.410 \pm 0.011^{\mathrm{a}}$ & $9.273 \pm 0.028^{a}$ & $1.685 \pm 0.006^{a}$ \\
\hline & $\mathrm{CT}$ & $166.242 \pm 0.943^{a}$ & $3.619 \pm 0.008^{a}$ & $3.178 \pm 0.010^{a}$ & $3.329 \pm 0.012^{a}$ & $4.348 \pm 0.011^{b}$ & $9.194 \pm 0.027^{a}$ & $1.687 \pm 0.005^{a}$ \\
\hline & $\mathrm{TT}$ & $157.095 \pm 1.545^{b}$ & $3.577 \pm 0.012^{b}$ & $3.161 \pm 0.016^{a}$ & $3.312 \pm 0.021^{a}$ & $4.294 \pm 0.016^{c}$ & $9.141 \pm 0.040^{a}$ & $1.657 \pm 0.009^{b}$ \\
\hline \multirow[t]{3}{*}{ A252G } & AA & $163.331 \pm 1.838^{a}$ & $3.578 \pm 0.011^{b}$ & $3.190 \pm 0.017^{a}$ & $3.309 \pm 0.021^{a}$ & $4.368 \pm 0.024^{a}$ & $9.238 \pm 0.048^{a}$ & $1.683 \pm 0.011^{\mathrm{a}}$ \\
\hline & $A G$ & $164.391 \pm 0.937^{a}$ & $3.628 \pm 0.008^{a}$ & $3.158 \pm 0.010^{a}$ & $3.317 \pm 0.012^{\mathrm{a}}$ & $4.344 \pm 0.010^{a}$ & $9.186 \pm 0.028^{a}$ & $1.678 \pm 0.006^{a}$ \\
\hline & GG & $164.236 \pm 0.901^{a}$ & $3.598 \pm 0.008^{b}$ & $3.189 \pm 0.010^{\mathrm{a}}$ & $3.334 \pm 0.012^{\mathrm{a}}$ & $4.383 \pm 0.011^{a}$ & $9.242 \pm 0.025^{a}$ & $1.683 \pm 0.005^{a}$ \\
\hline \multirow[t]{3}{*}{ A279T } & AA & $163.795 \pm 1.776^{a}$ & $3.609 \pm 0.015^{a}$ & $3.184 \pm 0.020^{a}$ & $3.361 \pm 0.029^{a}$ & $4.424 \pm 0.021^{\mathrm{a}}$ & $9.369 \pm 0.049^{a}$ & $1.693 \pm 0.012^{\mathrm{a}}$ \\
\hline & AT & $165.572 \pm 1.611^{a}$ & $3.624 \pm 0.015^{a}$ & $3.170 \pm 0.029^{a}$ & $3.335 \pm 0.023^{a}$ & $4.341 \pm 0.020^{a}$ & $9.261 \pm 0.056^{a}$ & $1.665 \pm 0.011^{\mathrm{a}}$ \\
\hline & $\mathrm{TT}$ & $162.034 \pm 2.486^{a}$ & $3.569 \pm 0.013^{b}$ & $3.182 \pm 0.021^{\mathrm{a}}$ & $3.294 \pm 0.026^{a}$ & $4.408 \pm 0.026^{a}$ & $9.224 \pm 0.061^{a}$ & $1.677 \pm 0.014^{a}$ \\
\hline \multirow[t]{3}{*}{ C281T } & $C C$ & $169.157 \pm 2.391^{a}$ & $3.674 \pm 0.027^{a}$ & $3.255 \pm 0.035^{a}$ & $3.391 \pm 0.057^{a}$ & $4.271 \pm 0.049^{a}$ & $9.305 \pm 0.087^{a}$ & $1.743 \pm 0.016^{a}$ \\
\hline & CT & $167.411 \pm 2.143^{a}$ & $3.644 \pm 0.018^{a}$ & $3.197 \pm 0.017^{a}$ & $3.372 \pm 0.024^{a}$ & $4.353 \pm 0.027^{a}$ & $9.268 \pm 0.053^{a}$ & $1.676 \pm 0.012^{b}$ \\
\hline & $\mathrm{TT}$ & $163.695 \pm 0.652^{b}$ & $3.602 \pm 0.005^{a}$ & $3.172 \pm 0.007^{a}$ & $3.316 \pm 0.009^{a}$ & $4.368 \pm 0.007^{a}$ & $9.211 \pm 0.019^{a}$ & $1.680 \pm 0.004^{b}$ \\
\hline \multirow[t]{3}{*}{ C293G } & CC & $162.034 \pm 2.486^{b}$ & $3.569 \pm 0.013^{b}$ & $3.182 \pm 0.021^{a}$ & $3.294 \pm 0.026^{a}$ & $4.408 \pm 0.026^{a}$ & $9.224 \pm 0.061^{\mathrm{a}}$ & $1.677 \pm 0.014^{a}$ \\
\hline & $C G$ & $165.070 \pm 0.961^{a}$ & $3.622 \pm 0.008^{a}$ & $3.155 \pm 0.011^{\mathrm{a}}$ & $3.308 \pm 0.013^{a}$ & $4.330 \pm 0.011^{b}$ & $9.174 \pm 0.030^{a}$ & $1.678 \pm 0.005^{a}$ \\
\hline & GG & $163.957 \pm 0.823^{b}$ & $3.605 \pm 0.007^{a}$ & $3.190 \pm 0.009^{a}$ & $3.339 \pm 0.011^{\mathrm{a}}$ & $4.380 \pm 0.010^{a}$ & $9.247 \pm 0.023^{a}$ & $1.684 \pm 0.005^{a}$ \\
\hline \multirow[t]{3}{*}{ С339Т } & $C C$ & $163.359 \pm 0.711^{b}$ & $3.599 \pm 0.006^{b}$ & $3.174 \pm 0.008^{a}$ & $3.322 \pm 0.009^{a}$ & $4.363 \pm 0.008^{a}$ & $9.218 \pm 0.020^{a}$ & $1.680 \pm 0.004^{a}$ \\
\hline & $\mathrm{CT}$ & $164.225 \pm 1.366^{b}$ & $3.617 \pm 0.012^{b}$ & $3.166 \pm 0.015^{a}$ & $3.312 \pm 0.019^{a}$ & $4.364 \pm 0.020^{a}$ & $9.197 \pm 0.044^{a}$ & $1.679 \pm 0.008^{a}$ \\
\hline & $\mathrm{TT}$ & $175.214 \pm 2.136^{a}$ & $3.695 \pm 0.022^{\mathrm{a}}$ & $3.243 \pm 0.024^{\mathrm{a}}$ & $3.369 \pm 0.030^{a}$ & $4.395 \pm 0.031^{a}$ & $9.288 \pm 0.069^{a}$ & $1.711 \pm 0.015^{a}$ \\
\hline \multirow[t]{3}{*}{$\mathrm{C} 458 \mathrm{~T}$} & $\mathrm{CC}$ & $161.517 \pm 0.936^{b}$ & $3.593 \pm 0.007^{b}$ & $3.170 \pm 0.010^{a}$ & $3.309 \pm 0.011^{a}$ & $4.330 \pm 0.010^{c}$ & $9.173 \pm 0.024^{a}$ & $1.675 \pm 0.005^{a}$ \\
\hline & $\mathrm{CT}$ & $167.580 \pm 0.890^{a}$ & $3.628 \pm 0.008^{a}$ & $3.180 \pm 0.011^{\mathrm{a}}$ & $3.330 \pm 0.013^{a}$ & $4.375 \pm 0.012^{b}$ & $9.216 \pm 0.030^{a}$ & $1.683 \pm 0.006^{a}$ \\
\hline & $\mathrm{TT}$ & $164.919 \pm 1.571^{a}$ & $3.608 \pm 0.013^{\mathrm{ab}}$ & $3.190 \pm 0.017^{\mathrm{a}}$ & $3.358 \pm 0.023^{\mathrm{a}}$ & $4.466 \pm 0.021^{a}$ & $9.396 \pm 0.044^{a}$ & $1.700 \pm 0.010^{a}$ \\
\hline
\end{tabular}

Note: If the letters in the same column are different, there is a significant difference $(p<0.05)$; if the letters in the same column are the same, there is no significant difference $(p>0.05)$.

of GnRH had evident impacts on egg yield of Liancheng white ducks. Yang T. (2007) proved the significant correlation between genotypes of $\mathrm{GnRH}$ and egg yield in Wanxi white goose. Peng L. (2013) detected AA, $A B$ and $B B$ genotypes on $G R 1$ segment of intron 2 of GnRHR gene in muscovy duck, which all showed significant correlations with laying start age, maximum number of continuous laying days, average number of continuous laying days and egg number of 300-day old ducks. Hu et al. (2015) pointed out that 3 SNPs of
GnRH gene influenced laying start age of Erlangshan chicken significantly and SNP5 played an important role in body weight at the beginning of laying. All these studies show that $\mathrm{GnRH}$ gene might regulate the production performance of poultry. Different from the reports above, this study analyzed the relationship between $\mathrm{GnRH}$ gene polymorphism and quail growth traits, and detected 14 SNP loci that were significantly related to body weight, shank length, breastbone length and shank circumference of quail. This study 
Bai J, Dong ZH, Lei Y, Yang YB, Jia XP, Li JYI

\section{Association Analysis Between Polymorphism of Gonadotrophin Releasing Hormone Genes and Growth Traits of Quail (Coturnix Coturnix)}

suggested that GnRH gene had certain effect on the growth traits of quail.

\section{ACKNOWLEDGEMENTS}

Sincere gratitude goes to the sponsor of National Natural Science Foundation (31201777) and IndustryUniversity-Research Cooperation Project in Henan Province (202102110088).

\section{REFERENCES}

Bai JY, Cao H, Yang S, Pang YZ, Jiang MJ, Fan HD, et al. Comparative analysis on early growth and development of different egg-laying quails. Indian Journal of Animal Research 2020;54(3):392-395.

Bai JY, Pang YZ, Qi YX, Zhang XH, Yun XY. Development and application of EST-SSR markers in quails. Brazilian Journal of Poultry Science 2016a;18:27-32. Special Issue

Bai JY, Pang YZ, Zhang XH, Li YX. Study on the morphological development of quail embryos. Brazilian Journal of Poultry Science 2016b;18:91-93. Special Issue 2

Bai JY, Pang YZ, Zhang XH, Yun YX, Qi YX. Microsatellite analysis of genetic diversity in quail populations from China. Brazilian Journal of Poultry Science 2016c;18(3):519-524.

Ding H, Gong YS, Wang J, Lv W F. Relationship between methylation status and expression of GnRH gene in small tail han sheep during onset of puberty. Chinese Journal of Animal Science 2018;54(5):58-61.

Du QZ. Genetic polymorphism of GnRH, LHR and PRL and their association with semen quality of Holstein cattle. Wuhan City: Huazhong Agricultural University;2011.

Gong YS, Ding H, Lv WF, Wang J. Distribution of dnmt1 and GnRH in the hypothalamus during puberty onset of ewe. Chinese Journal of Veterinary Medicine 2018;54(7):20-25.

Hameeda N, Khana MIR, Ahmada W, Abbas M, Murtazza A, Shahzad M, et al. Follicular dynamics, estrous response and pregnancy ratefollowing $\mathrm{GnRH}$ and progesterone priming with or without eCG during nonbreeding season in anestrous Beetal goats. Small Ruminant Research 2020;182:73-77.

Han XZ, Zhang KS, Zhong H, Hu YJK, Wang QG, Liu AF. Cloning, sequence analysis and prokaryotic expression for CDS of goose GnRH gene. Chinese Journal of Veterinary Science 2017;37(6):1173-1178.

He ZL. Study on the relationship between gene expression of GnRH, GnIH and VIP and reproductive performance in chicken [thesis]. Nanjing City (Jiangsu Province): Nanjing Agricultural University; 2009. (in Chinese).

Hu YD, Huang QK, Zhu Q. Identification and association of singlenucleotide polymorphisms in gonadotropin-inhibitory hormone $(\mathrm{G} \mid \mathrm{H})$ gene with egg production traits in Erlang mountainous chickens. Genetics \& Molecular Research 2015;14(1):294-303.
Huang ZB, Zhong ZX, Liu L, Qin GR, Wu X, Lian SY, et al. Correlation analysis on single nucleotide polymorphism of GnRH gene and laying performance in Liancheng Duck. China Poultry 2011;33(5):31-33.

Li YX, Zhang $X H$, Pang YZ, Qi YX, Zhao SJ. Construction of MC1R and ASIP eukaryotic expression vector and its regulation of plumage color in japanese quail (Coturnix japonica). Journal of Poultry Science 2019;56(2):84-90.

Li ZH, Li D. Association analysis on polymorphism of GnRH gene and reproduction traits in rongjiang small xiang goat. Hubei Agricultural Sciences 2016;55(8):2059-2061.

Liu L, Chen Y, Li N, Wang DW, Ren F, Song Y, et al. Molecular cloning, tissue distribution and expression of GnRH gene in different developmental stages of Lasiopodomys brandtii. Sichuan Journal of Zoology 2017;36(5):498-506.

Peng, L. Cloning, spatiotemporal expression and correlation of GnRHR gene of Muscovy duck. Fuzhou (Fujian Province): Fujian Agricultural and Forestry University; 2013.p.55-56. (in Chinese).

Pu YJ. Cloning and expression of genes related to laying quail and their correlation with traits. Wuhan City (Hubei Province): Huazhong Agricultural University 2016; p.42-58. (in Chinese).

Pu YJ. Study on cloning, expression and correlation of egg-producing related genes of egg quail with characters. Wuhan: Huazhong Agricultural University; 2016.

Rasul M, Mehmood S, Ahmad S, Javid A, Mahmud A, Rehman A, et al. Effects of different anti-stressors on growth, serum chemistry and meat quality attributes of Japanese Quail. Brazilian Journal of Poultry Science 2019;21(1):1-10.

Wang S, Zhang Y, Cheng Y, Lu G, Yang R, Geng H, et al. Association of SNPs in GnRH gene with sperm quality traits of Chinese water buffalo. Reproduction in Domestic Animals 2020;55:384-392.

Xu H, Zeng H, Luo C, Zhang D, Wang Q, Sun L, et al. Genetic effects of polymorphisms in candidate genes and the QTL region on chicken age at first egg. BMC Genetics 2011;12:33.

Xu HP, Zeng H, Zhang DX, Jia XL, Luo CL, Fang MX, et al. Polymorphisms associated with egg number at 300 days of age in chickens. Genetics and Molecular Research 2011;10(4):2279-2289.

Yan QM, Chen QJ, Cui YH, Zhu GQ, Zhu CM, An XP, et al. Polymorphism of GnRH gene and its relationship with little size and growth weight of xinong shaaneng dairy goat and boer goat. Chinese Journal of Veterinary Science 2011;31(11):1667-1671.

Yang T. SNPs detection of GnRH gene $5^{\prime}$ terminal regulatory region and exon 1 in geese and their relationship with egg production. Hefei (Anhui Province): Anhui Agricultural University 2007; p.26-28. (in (Chinese).

Zang ZL. Study on the expression and function of GnRH and LH in the corpus luteum of pregnant sows. Xi'an City, (Shaanxi Province): Northwest University of Agriculture and Forestry Science and Technology; 2019. (in Chinese).

Zhang KS, Hu YJK, Han XZ, Gao G L, Zhong H, Wang Q G. Analysis of the serum concentrations and mRNA expression levels of GnRH and $\mathrm{GnIH}$ in geese during different reproductive periods. Acta Veterinaria Et Zootechnica Sinica 2016;47(8):1720-1726. 